\title{
Links between Peace, Democracy and Human Rights
}

\author{
Los vínculos entre la paz, la democracia y los derechos \\ humanos
}

\author{
CHRISTOPHE BARBEY \\ Lawyer and peace researcher \\ APRED, Participative Institute for the Progress of Peace, Switzerland
}

\begin{abstract}
The construction of modern history partly relies on values and political tools available to the individual person: democracy and human rights. Using peace as a start point and moving through recent evolutions, this article explores links between democracy, human rights and peace, describing tools used for their respective and mutual progress. The place peace can take in constitutions is explored and the possibility and advantages of considering peace as a human right are presented. As «progress is in the making», the article shows avenues this progress may take and ways to participate in this evolution.
\end{abstract}

\section{KEYWORDS}

CONSTITUTIONS, DEMOCRACY, HUMAN RIGHTS, PARTICIPATION, PEACE

\section{RESUMEN}

La construcción de la historia moderna depende en parte de los valores y de las herramientas políticas que la personas tienen a su alcance como individuos: la democracia y los derechos humanos. Utilizando la paz como punto inicial y moviéndose a través de la evolución más reciente, este artículo explora conexiones entre la democracia, los derechos humanos y la paz, describiendo las distintas herramientas disponibles en sus respectivas y mutuas evoluciones. El lugar que la paz puede ocupar en las constituciones se explora en este artículo, junto a la posibilidad y la ventaja que tiene concebir dicha paz como un derecho humano. En tanto que «el progreso está en camino», el artículo muestra las avenidas transitables y los diferentes caminos disponibles para participar en esta evolución. 


\title{
PALABRAS CLAVE \\ CONSTITUCIONES, DEMOCRACIA, DERECHOS HUMANOS, PARTICIPACIÓN, PAZ
}

\begin{abstract}
The same species who invented war is capable of inventing peace.
The responsibility lies with each of us.

Seville Manifest on Violence, UNESCO, 1989.
\end{abstract}

\section{INTRODUCTION}

Peace, democracy and human rights are part of our human experience. They are what we built through history as an expression of our intentions for our future, as individuals and in social groups; for the human race and for our institutions. They have an ideal in common: they are human values required for the well-being of all. All these three fields of human activity share worldwide and local infrastructures and what has been accomplished in these fields is sufficient to show that they will continue to develop, in reach and quality.

Recent history has given a great push to all three of them. Europe, with some exceptions, has known a longer period of peace than at any time since the Roman Empire. The number of conflicts and victims are receding worldwide since the end of the Cold War. ${ }^{1}$ The foundations of peace have been laid deeper than ever in humanity's culture. Democracy and the rule of law are in progress around the world. Examples include the decrease in dictatorships, the bringing to trial of such leaders, the demand of the international community for democratic structures, the rising number of referendums, the expansion of representation to women, young people and foreigners. ${ }^{2}$ Human rights are also in progress. Signs of this progress encompass the recognition of the universality of human rights through the Universal Periodic Review process in which all nation-states undergo the review of their human rights record; the emergence of new rights like the right to a healthy environment or the human right to peace; the growth of civil and political rights through the territorial expansion

1 Lotta Themnér and Peter Wallensteen, Armed Conflicts, 1946-2012, Uppsala conflict data program, 4, available here: http://jpr.sagepub.com/content/early/2013/06/28/002234331349439 6.full.pdf+html. All websites accessed June 2014.

2 Data on the progress of democracy, F. Spagnoli, at http://filipspagnoli.wordpress.com/ stats-on-human-rights/statistics-on-freedom/statistics-on-democracy. 
of democracy; and the increased importance of social and economic rights through the Millennium Development Goals all show that life is becoming of better quality, for individuals, for humanity as for the human functioning of our sociopolitical structures.

From legal point of view as well as a practitioner's, this article will explore some of the links between these three fields of human activity, peace, democracy and human rights, showing how they are mutually reinforcing and needed together.

\section{LiNKS THROUGH THE DEFINITION OF PEACE}

Peace has traditionally been seen as an international matter with a definition of peace limited to the absence of war or conflict; that is negative peace. Because peace also includes the conditions needed for peace to last and to prevail -positive peace- it touches most realms of life. ${ }^{3}$

Political respect for peace has grown steadily through the consciousness of individuals as in the infrastructures of our civilization. Social aspects of peace improve through development and education, through better prevention and handling of conflicts and through greater demands for security and nonviolence. Individual aspects of peace develop through personal development, through the need for peace in the communities, for the future of humanity as a whole and through greater participation in political decisions. ${ }^{4}$

Peace roots itself as a feeling. Serenity and harmony can serve as synonyms. It is a proactive feeling as we participate (or not) in the upholding and creation of peace. We nourish peace with our emotional and intentional inputs as well as through our knowledge, skills and practices. This is useful to distinguish and to remind ourselves of the distinction between dialogue and debate, between common construction or argument, conflict and oppositional positions. Peace is thereby both the means and the purpose needed to establish or to return to a state of serenity and harmony, to a common understanding and a peaceful modus vivendi.

3 J. Galtung, «Violence, Peace and Peace Research». Journal of Peace Research, 6, 3 (1969), 167-191.

4 International Covenant on Civil and Political Rights, 1966, article 25: «Every citizen shall have the right and the opportunity, [...] without unreasonable restrictions: (a) To take part in the conduct of public affairs, directly or through freely chosen representatives; (b) To vote and to be elected at genuine periodic elections which shall be by universal and equal suffrage and shall be held by secret ballot, guaranteeing the free expression of the will of the electors». http://www.ohchr.org/en/professionalinterest/pages/ccpr.aspx. 
Still looking at peace as a feeling, we realize that like life, peace precedes its definition. Without the lens of a definition, it is easy to see that we need some degree of peace to allow the basic activities of our lives like eating and resting, loving and raising our children. So forth, we need peace for our greater deeds and projects, as for the survival of our species. More often than not, we are at peace without noticing it or calling it «peace». The notion of peace is closer to our needs and thoughts than what we sometimes imagine it.

If we then acknowledge that we can improve peace and choose to reduce violence, we may ask ourselves: are we part of the solution or part of the problem; do we work toward peace or do we hinder its progress by adding trouble to the state of the world and to the quality of our own lives? We can also leave the past behind, or heal and learn from it and work on our present happiness and peace for a lasting future.

Peace then becomes intent and here the definition of peace asserts its full importance. How a person or an institution defines peace will have a direct effect on the way issues of peace are addressed, specifically in situations of conflict be they great or small. The higher the ideal, the more likely it will be that conflicts will be prevented or, if need be, peacefully resolved. Moreover, clear peace policies will help design and readily implement available peace tools to address conflicts without aggravating them or without the need to resort to force to address them, to restore and to reestablish peace. Moreover, as fewer damages and burdens are added to the problem, the easier it will be to extract lessons learned from it and to avoid reoccurrences of similar situations.

There is here a proactive dimension to peace: it prepares preventive and humane ways to address conflict and difficulties of all sorts. Human rights, as they empower people to live their lives fully are also proactive. Here, peace and human rights merge. They are oriented toward the peaceful and individual achievement of universal values. Their methods and procedures may vary, yet they do not exclude each other as there is no peace without justice and without the fulfillment of all human rights. Though human rights must be respected in times of conflict, human rights also still participate in the establishment or reestablishment of peace. ${ }^{5}$

Beyond misunderstandings, disagreements and personal interests, peace is

5 Another reference on peace and human rights: M. Parlevliet, Connecting Human Rights and Conflict Transformation. Eschborn, Deutsche Gesellschaft für Internationale Zusammenarbeit, 2011,

http:/www.giz.de/Entwicklungsdienst/de/downloads/giz2011_en_hr-and-conflict-transformation.pdf.pdf. 
the choice of an overarching value to avoid strife, conflict and destruction. It is the choice of a personal, social and political system and of the tools needed to lead us into comprehension, human viability and sustainability. Political and democratic influences are important for the effectiveness of peace. When the choice for peace is made by a political choice and confirmed in an institutional structure, then peace can stand as a guide for the people and serve as a tool of governance, thus mainstreaming peace. Having peace as a central element of politics, in the same way that gender balance and environmental protection are or should be, implies that all are concerned with peace, with rights and duties, but also that peace will be studied, promoted and practiced in order to progress. Tools of peace will be designed and made available for peace to be achieved and maintained. ${ }^{6}$ We will describe some of these tools below.

It is because we live happily in peace or because we have the possibility of living in peace that the place of peace in our sociopolitical structures needs to be acknowledged. Good feelings are meant to be shared, skillfully. Good values are meant to be chosen, universally.

\section{LINKS THROUGH HUMAN RIGHTS}

Human rights are peace-prone; they favor peace. They limit the capacity of the state to abuse power; they are meant to be lived and defended if need be. They empower the people to live freely and happily. Looking at the links between human rights and peace, we will show the major exceptions to the human rights system and how peace can lessen these restraints on our essential freedoms. We will then present the advantages of recognizing peace as a human right.

\section{III.1 LINKS BETWEEN PEACE AND HUMAN RIGHTS}

We recall here one of the basic principles of the human rights system: liberty. Ideally, people make proper decisions in order to maintain their personal freedom and the freedom of others. They have the means to control restrictions on freedoms and to limit or diminish the consequences of the abuse of power. Yet, this is a conflict-oriented or defensive perspective on freedom and institu-

6 Development agencies, public and private, largely include conflict sensitivity to their programs, some examples: www.berghof-foundation.org/en; http:/www.swisspeace.ch/topics / analysis-impact.html;

http://cdacollaborative.org. 
tions. In a cooperative and proactive perspective «we the peoples» ${ }^{7}$ enjoy our freedoms together and in peace instead of against each other or against our institutions. The relationship with institutions and political authorities could be either cooperative or authoritative. Finding democratic and non conflictive ways to enhance the relationship between people and institutions is a way to move peace, human rights and democracy forward.

\section{III.2 EXCEPTIONS TO HUMAN RIGHTS SYSTEMS}

The guarantee of freedom should be absolute. Presently, it suffers four exceptions: the death penalty; economic and social rights; criminal law; and international peace.

The death penalty, by purposefully killing people does not enhance freedom or peace. Non-killing societies are essential for the fulfillment of human rights, for the progress of peace and democracy. ${ }^{8}$ Institutions are made to serve all the people and they do so by their own example. As such, killing people is in no way exemplary nor does it promote the right to life for all the people. Conversely, enhancing peace values promotes the right to life and to a good life for all, thus enhancing preventive efforts for the preservation and the respect of life by all.

Economic and social rights have a similar effect. Deprived of essential needs, people do not enjoy their liberties and may be inclined to resort to violence. Moreover, they are busy surviving and are unable to participate in the decision-making processes that concern them. They have no say regarding the way humanity manages its affairs, much less how to manage their own wellbeing and their opportunities to escape poverty, to overcome economic strife and to live their lives in dignity. The absence of fulfillment of economic and social rights is a major cause of «non-peace»; poverty causes violence, crime, migrations and conflicts over resources. ${ }^{9}$ Conversely, fulfilling these basic living rights all over the world, sharing a part of humanity's wealth and resources to enhance the quality of life and peace for all reduces crimes and violence.

7 Charter of the United Nations. Preamble. «We the peoples of the United Nations, determined [...]», http://www.un.org/en/documents/charter/preamble.shtml.

8 On non-killing, see the works of the Center for Global Non-killing: http://www.nonkilling. org. On peaceful societies, G. Kemp and D. Fry, (eds.), Keeping the Peace: Conflict Resolution and Peaceful Societies around the World. (New York: Routledge, 2004).

9 Links between violence and development: «Geneva Declaration on Armed Violence and Development» http://www.genevadeclaration.org. Also: World Development Report 2011: Conflict, Security, and Development. (Washington DC: World Bank). 
In another dimension of the same problem, worldwide annual military spending is presently ten times greater than worldwide development assistance. ${ }^{10}$ Increasing the well-being of all therefore reduces the need for resources devoted to security and war, or to the potentials of war. But the opposite is also true: reduction in military spending diminishes the risk of war and liberates resources to improve the well-being of all. Therefore, more democratic control of military budgets, too often lacking transparency, and more policies oriented toward human well-being and sustainability will enhance peace, human rights and democracy. ${ }^{11}$

The criminal justice system, with its legally organized possibility to punish, is one of greatest infringements on freedom. However a punishment may seem deserved or be deemed necessary, human rights systems and criminal justice systems protect roughly the same legal elements or values, though using very different languages and methods to do so. Human rights are proactive and empowering while criminal law is directive and repressive. Crime prevention efforts have not reached their full potential partly because people confident that their rights can and will be fulfilled -in other words happier people- will contribute to the progress and sharing of human rights and peace and will be much less attracted to crime. They will also be more willing to participate in the democratic process. ${ }^{12}$

Though growing fast, the human rights system has had little direct impact so far on international peace, a field still largely left to the power of nationstates under the relatively weak control of the United Nations. Yet if there is a right to peace for nation-states and for humanity itself, then the people deserve such a right as well, a human right to peace, discussed below.

These four exceptions to the human rights system all entail deep breaches of freedom, peace and well-being and hinder the democratic process. However, we have shown that bringing peace, democracy and human rights together offers solutions for these difficulties.

10 On military spending, see the statistics at the Stockholm International Peace Research Institute (SIPRI): http://www.sipri.org/research/armaments/milex/recent-trends. On development assistance, see the report from the United Nations on development assistance: The Millennium Development Goals Report, 2013. (New York: United Nations, 2013), p. 52, available online,

http://www.undp.org/content/dam/undp/library/MDG/english/mdg-report-2013-english.pdf.

11 On democratic control of armed forces: http://www.dcaf.ch/Programmes/Parliamentary-Oversight. On disarmament for development: http://www.ipb.org/web/index. php? mostra $=$ content\&menu $=$ Military $\% 20$ vs. $\% 20$ Social $\% 20$ Spending \& submenu $=\% 20$ Imbalance $\% 20$ between $\% 20$ development $\% 20$ and $\% 20$ defence $\% 20$ budgets.

12 Additionally, happy people will be more inclined to preserve the planet upon which they live. 


\section{III.3 The HUMAN RIGHT TO PEACE, THE PARAMOUNT LINK BETWEEN PEACE AND HUMAN RIGHTS}

Peace grows in many directions. Besides more traditional political and social realms of peace, individuals manifest their concerns regarding peace and participate in the progress of peace in many ways, including through non-violent actions and revolutions. They participate in the construction of a more peaceful world and contribute to the general understanding that violence is not a solution. People claim peace not only as a peaceful setting for themselves and for society, but also as a tool of transformation, as an inherent part of our natural and intended evolution. So do people have a right, a human right, to peace?

War has been illegal since the adoption of the United Nations Charter. ${ }^{13}$ The only tolerated exception is self-defense and it is severely restricted in legal terms and therefore does not justify the tremendous war and military efforts still going on. ${ }^{14}$ Peace has made great progress in recent decades but to «save succeeding generations from the scourge of war» ${ }^{15}$ and to abolish war altogether new tools are needed. Recognizing that peace is or could be a human right is one of them.

The idea is not new. The Universal Declaration of Human Rights states that «Everyone is entitled to a social and international order in which the rights and freedoms set forth in this Declaration can be fully realized». ${ }^{16}$ Such an order, a right in itself, is a peaceful order. From another perspective, the right to safety and security, in some respects equivalent to the right to peace, is recognized in all major human rights texts. ${ }^{17}$ Since 2007, the United Nations Human Rights Council has been discussing the issue of a specific human right to peace ${ }^{18}$, the objective being to see full recognition of peace as a human right, in a binding text. However, such recognition is not necessary to know we have the right to live in peace and to claim it whenever needed.

13 UN Charter, Article 2, 3 and 4. http://www.un.org/en/documents/charter/chapter1. shtml.

14 UN Charter, Article 51. http://www.un.org/en/documents/charter/chapter7.shtml.

15 UN Charter, preamble. http://www.un.org/en/documents/charter/preamble.shtml.

16 Article 28, http://www.un.org/en/documents/udhr/index.shtml\#a28.

17 On the human right to peace, see Pace Diritti Umani, Special Issue on the Right to Peace, 2-3, 2012 or Christophe Barbey, «Faire de la paix un droit humain. Une nécessaire evidence. [To make peace a human right. A necessary evidence]», in C. V. Durán and C. F. Pérez (eds.), Contributiones regionales para une declaration unisersales del derecho humano a la paz. (Luarca: AEDIDH, 2010), 435-459.

http://aedidh.org/sites/default/files/Contribuciones-regionales_0.pdf

18 Human rights council on the human right to peace: http://www.ohchr.org/EN/HRBodies/ HRC/RightPeace/Pages/WGDraftUNDeclarationontheRighttoPeace.aspx 
The theoretical analysis of the right to peace shows that it brings new dimensions to the human rights system. From a proactive and peaceful perspective, it transcends a defensive approach to human rights, enhancing empowerment, cooperation and serene fulfillment of all human rights. It is therefore a right synthesizing all other rights.

To be coherent, the human right to peace needs to be exercised peacefully. As such, it enhances preventive measures to avoid conflict, violence and reoccurrences of violations of peace or rights. Thereafter and whenever needed, it encourages cooperation, mediation and other alternative or traditional and non-violent dispute-resolution mechanisms available for the peaceful settlement of disputes. Henceforth, it encourages peaceful relations for the exercise and the coordination of all human rights, thus giving more cohesion to the human rights system as a whole. Human rights form a complete system, but therein peace is needed as a cooperative right and as a tool for the fulfillment of all human rights.

Furthermore, the human right to peace does not only protect every person from breaches of peace by the State; it also functions very well as a multidirectional right. All individuals and human groups are entitled to live and thrive in peace, so everyone bears the responsibility of granting peace to all. This interactive dimension reconciles rights and duties for a common share of rights.

For this to function there is a need for positive governmental action. This starts with the symbolic proclamation of the right to peace, thus giving legal value to the saying «I have the right to live in peace». It continues with the duty to provide peace tools to the people through education and as well as peaceful mechanisms for preventing and solving conflicts.

Governments will benefit from their efforts for peace. As sole bearers of the monopoly on the use of force, states are accountable for peace, uses of force and breaches of peace. The more they invest in prevention and peacebuilding, the fewer occasions will arise for their accountability.

Nevertheless, if peace enhancement and prevention fail, protecting peace may require the use of force to restore peace. The tools used to stop and redress violations of the human right to peace imply a judicial control over the way peace and force are handled by a given state. This control can be judicial, but more preventively, regular state reports on the situation and moreover on the progress of peace in their jurisdiction will be an excellent tool for monitoring the way states work to reduce violence and improve peace.

The advantages of making peace a human right are numerous; people, the human rights system and governments will all benefit from it. It will make states less prone to violence and therefore render democracy more accessible and legitimate. 


\section{LINKS THROUGH DEMOCRACY}

The history of democracy is the history of a struggle against discrimination to gain the right to participate in the decision process. Inclusiveness is only possible in a peaceful environment because any form of exclusion -a form of violence and excess of power in itself-will prevent participation. In fact, even the rule of the majority can have strong excluding effects. Therefore, consensus procedures and mechanisms facilitating participation, personal initiative and power sharing will be of greater importance in the future. We will use two examples to show this: the place of peace in constitutions and new forms of democratic participation. Some thoughts are needed on the relation between peace and democracy prior to the discussion of the examples.

\section{IV.1 Peace And the democratic order}

A peaceful democracy is more than a matter of persons and infrastructures. ${ }^{19}$ War, violence and conflict are still too often on the agenda, maybe simply because the democratic process as a struggle for power can itself be wrathful. Nevertheless, though far from perfect, democracy serves as a method for regulating and solving conflicts or at the least as a way to balance powers. So if in itself democracy is not sufficient to ensure peaceful relations, at least it usually prevents physical violence and armed struggles for power, at least internally. Nor is democracy, in the absence of other peace tools, a guarantee of peace in the international order. Some intolerable regimes were elected (the Nazis, the Italian fascists) and this explains why the founders of the present human rights system thought it so important to have popular control over governments. Human rights can stop massive abuses early on through the liberty possibility given to the people to claim their rights. Presently, we also have belligerent or bellicose countries that are or seem to be functioning internal democracies, while easy at waging war or at promoting violence outside their realms (USA, Israel, Iran). Nevertheless, not all democratic states have a warprone tendency. So though it is states and quite often democratic states that make war possible through their armies and weapons industries, it is not the State as an institution -one of the existing structures of power- rather it is some states among them-democratic or not- that are the systemic or root cause of military conflicts.

19 On infrastructures for peace: Barbara Unger, Stina Lundström, Katrin Planta and Beatrix Austin, (eds.), Peace Infrastructures. Assessing Concept and Practice. (Berlin: Berghof foundation, 2013). Also: Global Alliance for Ministries and Infrastructures for Peace, www. gamip.org. 
Similarly, the fact that many democracies are involved in military activities does not mean democracy is at fault for the existence of war. Moreover, since not having an army is a fair guarantee for having a functioning democracy, ${ }^{20}$ improving democracy should reduce the risks and potentials for war. However, a large part of the burden of abolishing war is still on nation-states, so having peace as a goal and a constraint for all national and international activities should be a requirement for the existence of a state. ${ }^{21}$ In fact, Article 4 of the United Nations charter stipulates that only «peace-loving» nations can be members of the United Nations (UN) and it is worth noting that the United Nations is by now a universal organization as all fully recognized nation-states are now members. Are they all fully peace-loving states? Meanwhile and until this becomes an applied fact, we have or should have more democratic control over our nation-states and should create more tools to help them become more peace loving. Thus, improving the democratic participation of the people also improves peace.

There is hope. There is a trend toward more peaceful societies and states will progressively follow it. It arises out of the fear of war, for survival needs or because peace is part of a sustainable future. People, societies and institutions have started to understand that peace has its own merits and benefits, thus asking for peace by peaceful means. Peace becomes a more common practice and a standard for measuring the way things are done. This trend is present in the international arena where war is more systematically rejected, while democracy and human rights are becoming more often required. This trend is supported by the activities of a growing academic community researching and working for peace and conflict prevention. The diversity of the peace movement and the civil society concerned by peace, their growing efficiency also reflects this trend and development policies of the international community increasingly integrate awareness of the effects of their actions on conflict - that is conflict-sensitivity- to their programs.

A paradigm shift is slowly occurring. The state is leaving behind what has been often called the authoritarian regime or the police state and is moving toward

20 Out of 26 countries without armies identified in 2013, 25 are democratic regimes, the Holy See being the exception. Only two of them, the Solomon Islands and Haiti, have in recent decades experienced events that disrupted the democratic order. Christophe Barbey, Non-militarisation Throughout the World. Countries without Armies and Peace Policies. Part One: Identifying the Countries without Armies. (Mariehamn: Åland Islands Peace Institute, report series, 2014).

21 The supreme court of Costa Rica states that peace is an essential part of any governing institution representing the people. Roberto Zamora Bolaños, «Reconocimiento y aplicación judicial del derecho humano a la paz en la jurisprudencia del Tribunal Constitucional de Costa Rica», in C. V. Durán and C. F. Pérez, (eds.), Contribuciones regionales para una declaración universal del derecho humano a la paz. (Luarca: AEDIDH, 2010), 419-435. 
a values-driven state, oriented toward sustainable and humane solutions, at the service of the people through cooperative practices. The state and its institutions are accountable for their own violence and mistakes, so they continue evaluating their work in an attempt to see what lies ahead and to create better conditions for their populations. These tools of governance will help to accelerate, peacefully, the adaptation of states and their people to the changes needed for the well-being of all, for a lasting and peaceful future for humanity.

From this perspective, it may seem that nation-states are the most potent bearers of the democratic process. Scrutiny shows that this is not always the case. Nation-states have not been so keen thus far to grant the people more democratic rights at continental and planetary levels. Federations, local states or even cities are often quicker to adapt and to grant new democratic rights. Moreover, it is often outside official public structures, through popular movements, in civil society and even in business companies that authority is progressively replaced by cooperative systems.

Improving democracy is a great challenge. Peace and human rights have their share in the process; peace loosens some of the tensions power creates, facilitating dialogue and lessening the need for the use of force or for preparedness for war. Human rights empower the people and encourage them to participate in the creation and in the decisions related to the well-being of all. One of the possibilities available to help states progress toward peace is to introduce more peace into their constitutions.

\section{IV.2 Peace and constitutions}

Constitutions are locally «universal» in that they relate to everyone in a given territory. They also have some influence abroad. They are at the root of the democratic system, the ruling rights and obligations of persons and institutions. Integrating peace, new democratic procedures and new rights in their text; concretizing peace, human rights and more democratic power are ways to encourage good relations between the state and the people, among the people themselves and in a broader sense, between all states and all people. There are annually around fifteen constitutional revisions. ${ }^{22}$ Two recent Swiss experiences illustrate the theory. More examples are available. ${ }^{23}$

22 M. Suksi, Referendums in Constitution Making Processes. (Geneva: Interpeace, 2010). http://www.constitutionmakingforpeace.org/sites/default/files/guidance_papers/InFocus_Suksi_FINAL.pdf

23 The Swiss constitution was fully revised in 1999, the constitutions of the cantons of Vaud in 2003 and Geneva in 2012. 
Where in a constitution should peace be mentioned? Preambles often mention peace. All major states and the UN Charter affirm that peace is an essential value. ${ }^{24}$ Preambles orient the whole text of the constitution, yet this mention is often of a declaratory nature and thus a good start, though insufficient. Some constitutions mention goals the state should achieve. These goals should include peace, an ideal to reach progressively. ${ }^{25}$ Fulfilling human rights and encouraging participation in the democratic process should be mentioned as well and, further in the text, receive concrete means to progress and be achieved, such progress being duly monitored. Peace, conflict-sensitivity and prevention mechanisms should be integrated in all state activities as should be the rule of law, human rights, gender balance and respect for the natural environment. ${ }^{26}$ Peace is to be integrated in human rights as we seen through the addition of the right to peace, eventually through an extension of the right to safety. ${ }^{27}$

All state missions should be crafted with a conflict-sensitive approach, though some are more directly concerned with peace. International relations and development cooperation should be mentioned and include the promotion of peace, democracy and human rights. ${ }^{28}$ «Friendly relations» and «pacific

C. Barbey, «La démarche constitutionnelle en faveur de la paix dans les États fédérés: Expériences faites à Genève et dans le Canton de Vaud. [The constitutional process in favor of peace in federated states: experiences from Geneva and Vaud]», in J. Mekhantar and R. Porteilla, (eds.), Paix et constitutions. (Dijon: University of Burgundy, 2014).

24 Christophe Barbey, «Peace in the Constitutions of the Members of the Security Council, of the Candidates to the Council and of some other States», in Une Suisse sans armée 73 (2007), 13.

http://www.demilitarisation.org/spip.php?article88.

25 Examples of goals are found in article 2, Swiss constitution, http://www.admin.ch/opc/ fr/classified-compilation/19995395/index.html\#a2 or Art. 10, Bolivian constitution, http://www. presidencia.gob.bo/documentos/publicaciones/constitucion.pdf .

26 Constitution of the Swiss canton of Vaud, art 6, 2, c: «In all its activities [the state] shall see to it that: [...] justice and peace prevail and [it] supports conflict prevention efforts» (translation by the author). «Art. 6 Buts et principes. [...] Dans ses activités, il: [...] c. fait prévaloir la justice et la paix, et soutient les efforts de prévention des conflits» http://www.admin.ch/opc/fr/ classified-compilation/20030172/index.html\#a6.

27 The human right to peace can also be integrated in the constitutional order through tribunal decisions. See above, R. Zamora, note 21.

28 Swiss constitution, art. 54: «The Confederation [...] shall in particular assist in the alleviation of need and poverty in the world and promote respect for human rights and democracy, the peaceful co-existence of peoples as well as the conservation of natural resources». Constitution of Geneva, art. 146: «It [the State] has an international solidarity policy supporting the protection and realization of human rights, peace, humanitarian action and development cooperation». http://www.admin.ch/opc/fr/classified-compilation/20132788/index.html\#a146. 
coexistence among states» are often mentioned. ${ }^{29}$ Some countries have gone as far as banning war ${ }^{30}$ or the existence of an army ${ }^{31}$ Education for peace should prepare the people for a civic and harmonious life, including peaceful conflict-management. ${ }^{32}$ Policies to prevent violence should be in the constitution, with adequate means to make them efficient. However, governments can also adopt such measures and programs without constitutional provisions. ${ }^{33}$ Policies facilitating conflict-resolution avoids further damages and reoccurrences. Methods such as ombudsmen, meditation and traditional or non-violent methods belong in the constitution. We suggest a right of access to such «soft justice» procedures. The way the state assumes its duty to preserve public order and the way it manages security forces should also be mentioned. This supposes regulating and ensuring independent monitoring of the use of force. ${ }^{34}$ Futurology and evaluation of governmental policies are important elements of good governance. ${ }^{35}$ Foreseeing the future is important, as are setting objectives and reporting on their achievement. All these state missions can be seen as peace policies, policies which can also be adopted by other agents of society.

Finally, the right of participation facilitated by constitutional rights deserves special attention. Constitutional and legislative referendums open up the discussion, moreover if citizens can call a referendum by collecting a sufficient number of signatures. This gives more responsibility to the people and better accountability for the governments. It offers opportunities for dialogue and peaceful change when needed. The obligation to ensure or at least retain the possibility of organizing large public consultations on proposals for new

29 Montenegro (art. 15), Timor Leste (6), etc.

30 Italy (art. 11), Japan (9), Ecuador (416), Bolivia (10).

31 Costa Rica (12), Panama (305), Kiribati (126), Liechtenstein (44). Japan constitutionally bans the army (9) though in fact it has one.

32 Geneva, art. 193: «The goals of public education are: [...] b) the promotion of human values and scientific culture; c) the development of civic and critical thinking». http://www. admin.ch/opc/fr/classified-compilation/20132788/index.html\#a193.

33 Policies adopted to reduce violence can be measured. See the Geneva Declaration, note 9 .

34 Geneva, art. 184, § 3: «Conflicts shall be handled in priority without resorting to force, or with limited force if need be. Concerned persons have a duty to help» (translation by the author). http://www.admin.ch/opc/fr/classified-compilation/20132788/index.html\#a184

35 Switzerland and Vaud have a futurology commission, Geneva has an evaluation mechanism. The latest Swiss futurology report: the www.bk.admin.ch/themen/planung/04632/index. html?lang=fr; And Vaud: www.vd.ch/fileadmin/user_upload/organisation/gc/fichiers_pdf/459 TexteCE.pdf 
laws has its place in constitutions. They encourage responsibility and have a peaceful effect on the political debate. ${ }^{36}$

\section{IV.3 OTHER TYPES OF DEMOCRATIC PARTICIPATION}

Democracy is evolving. The «Arab Spring» and the «Occupy» movement have shown that very large crowds of people can make decisions by consensus. Electronic voting is being tested. If people had the option of participating more, and the feeling that they are effectively partaking in the decision process, would they actually participate. A major change has occurred since the philosophy of the Enlightenment, which claimed «the greatest good for the greatest number». Modern human rights raise the standard differently: «maybe not as great a good, but sufficient for all». Knowing rights will entail sharing their responsibility and rights are indeed granted to all, including the right to participate in political decisions. ${ }^{37}$ One could wonder what would happen if the people had a right of veto (as the members of the Security Council have). In fact, this is what consensus procedures propose. The question is not about winning a majority for one type of a future or for another, it is about all having the right to a future and building it together. The right to say no, even one against all, allows individuals to express their disagreement while still being considered part of the community. This right however is only a right to further discussion, not the right to block the decision. Talking things over requires time but done properly most often it works. Sometimes the person in opposition will take personal initiative without referring to the group, which can be empowering too, especially if the initiative is thereafter approved by the group. Other times the group will resort to a vote or the person or minority will leave the discussion.

Nevertheless, without a right to say no and an equal right to hear why no is being said, there is no possible guarantee that all the rights of all the people concerned have been duly taken in account for the decision. Furthermore, without a consensus procedure, there is no learning space provided for the full empowerment of everyone to effectively participate in the decision process, whatever their opinion may be. Finally, it is through consensus procedures that peace and human rights for one and all merge into the decision process called democracy.

36 For more references and works on the place of peace in constitutions, see C. Barbey, note 23.

37 See note 4. 


\section{CONCLUSION}

In examining some of the links between peace, democracy and human rights, we have shown that these three structural values and processes are enshrined in human nature just as they are in institutions; they highly benefit from each other and they cannot prosper without one another. We have also shown some of the possible avenues by which humanity may progress, using the possibilities these values and their recent evolutions offer, for the sake of humanity's own dignity as well as for the common good.

Will peace, human rights and democracy help humanity overcome some of the survival issues we are presently facing? Human rights and democracy have a capacity to create a peaceful space, where we human beings become free to create the best system for ourselves and for our future. Because we are capable of making progress, no matter what, and because concrete possibilities are, as presented, available, we have good reason to believe that the progress of peace, democracy and human rights is possible and worth the effort and that they have their part in the betterment of the human condition. As quoted in the dedication: «the responsibility lies with each of us». 